\title{
REPRODUCIBILITY OF PHYSIOLOGICAL VARIABLES OF THE SIX-MINUTE WALK TEST IN HEALTHY STUDENTS
}

\section{Reprodutibilidade das variáveis fisiológicas do teste de caminhada de seis minutos em escolares saudáveis}

\section{Patrícia Morgana Rentz Keila (D), Janaína Cristina Scalco ${ }^{(\mathbb{B},}$ Renata Maba Gonçalves Wamosy ${ }^{a}$ (D), Camila Isabel Santos Schivinskia,* (D)}

\section{ABSTRACT}

Objective: To verify the reproducibility of the six-minute walk test (6MWT) performance and its physiological variables in healthy students.

Methods: This is as prospective cross-sectional study. The sample consisted of healthy students aged $6-12$ years old from public and private schools in the region of Florianópolis City, Santa Catarina State, (Southern Brazil). The medical state was considered according to the health records and scores on the International Study of Asthma and Allergies in Childhood (ISAAC) and the spirometric values of forced expiratory volume in the first second and forced vital capacity above $80 \%$ of what was predicted. Two $6 \mathrm{MWTs}$ were conducted with a 30-minute interval between them, following the recommendations from the American Thoracic Society. Physiologic variables were recorded using the portable telemetric gas analyzer K4b2 (Cosmed ${ }^{\circledR}$, Italy). For analysis, the dyspnea index, the perception of effort and performance variables identified in both 6MWT were considered. Data distribution was verified with the Shapiro-Wilk test and statistical analysis included paired t-test or Wilcoxon test, and intraclass correlation coefficient (ICC). The significance level adopted was 5\%.

Results: A total of 22 students with a mean age of $10.2 \pm 1.5$ years participated in the study. The covered distance and the variation of oxygen consumption reproducibility between the two 6MWTs presented ICC $=0.76$ and ICC $=0.86$, respectively. There was also similar behavior of the physiological variables when comparing the two tests ( $p=0.001)$, especially the minute volume $(M V)$, the oxygen consumption $\left(\mathrm{VO}_{2}\right)$, and the carbon dioxide production (VCO2).

Conclusions: The 6MWT showed reproducible values, both in performance and physiological parameters, in the healthy students analyzed.

Keywords: Child; Reproducibility of results; Walking.
RESUMO

Objetivo: Verificar a reprodutibilidade do desempenho e das variáveis fisiológicas do teste de caminhada de seis minutos ( $\mathrm{TC}_{6}$ ) realizado por escolares saudáveis.

Métodos: Estudo transversal prospectivo. A amostra foi composta de escolares saudáveis, entre 6 e 12 anos, provenientes de escolas públicas e privadas da Grande Florianópolis, SC, Brasil. A higidez foi controlada por meio do recordatório de saúde, do questionário International Study of Asthma and Allergies in Childhood (ISAAC) e dos valores espirométricos de volume expiratório forçado no primeiro segundo $\left(V_{E F}\right)$ e capacidade vital forçada (CVF) acima de $80 \%$ do predito. Foram registradas as variáveis fisiológicas utilizando-se o analisador de gases telemétrico portátil K4b2 (Cosmed ${ }^{\circledR}$, Itália), e, para análise, consideraram-se o índice de dispneia, a percepção de esforço e as variáveis de desempenho identificadas nos dois $\mathrm{TC}_{6}$. Verificou-se a distribuição dos dados pelo teste de ShapiroWilk, e a análise estatística incluiu: teste $t$ de Student pareado, ou teste de Wilcoxon, e o coeficiente de correlação intraclasse (ICC). O nível de significância adotado foi de $5 \%$.

Resultados: Participaram 22 escolares com idade média de $10,2 \pm 1,5$ anos. Identificou-se reprodutibilidade da distância percorrida e da variação do consumo de oxigênio entre os dois $\mathrm{TC}_{6}$, com ICC $=0,76$ e ICC $=0,87$, respectivamente. Houve similaridade no comportamento das variáveis fisiológicas na comparação entre os dois testes $(p=0,001)$, destacando-se o volume minuto $(V E)$, o consumo de oxigênio $\left(V_{2}\right)$ e a produção de dióxido de carbono $\left(\mathrm{VCO}_{2}\right)$.

Conclusões: O TC 6 apresentou valores reprodutíveis tanto no desempenho como nos parâmetros fisiológicos nos escolares saudáveis estudados.

Palavras-chave: Criança; Reprodutibilidade dos testes; Caminhada. 


\section{INTRODUCTION}

Functional status is a multidimensional concept that refers to how an individual is able to complete activities of daily living (ADL), which are essential to meet their physical, psychological and social needs. ${ }^{1}$ This term can be measured in four distinct segments: functional performance, functional reserve, functional utilization capacity and functional capacity, the latter concerning the individual's maximum potential to perform ADL. ${ }^{1,2}$ Functional capacity can be assessed with field tests, ${ }^{3}$ like the Sit to Stand Test, the AVD-Glittre adapted for children, the Stepping Test and the Six-Minute Walk Test (6MWT). ${ }^{4-7}$

Considering that the 6MWT is easy to apply, is safe, has a low $\operatorname{cost}^{8}$ and measurement properties and reference equations established for different pediatric populations, ${ }^{9}$ it is the most used test in the assessment of the functional capacity of children and adolescents. The test performance is attributed to the distance covered (DC) in meters, during the six minutes, which is considered a sensitive and important measure to monitor responses to therapeutic interventions of children with different dysfunctions, ${ }^{10,11}$ in addition to being a predictive measure of morbidity and mortality. ${ }^{12}$

However, the 6MWT does not yet have protocols or specific guidelines for its application in Pediatrics, because the American Thoracic Society (ATS) and European Respiratory Society (2014) documents standardize the application of this test based on studies including adults with chronic respiratory disease. ${ }^{10}$ Today, it is recommended to perform two 6MWTs, with an interval of 30 minutes between them, considering a possible learning effect observed in the adult population. ${ }^{13}$ However, in Pediatrics, such behavior is still controversial. ${ }^{8,14-16}$ In this group, the influence of anthropometric factors on test performance is discussed, as they are growing and developing, and there is a need for more specific technical standards for the age group, such as verbal command and pictorial effort scales. ${ }^{17}$

That said, it is necessary to know the behavior of the cardiovascular, ventilatory and metabolic demands induced by the 6MWT when it is performed by the pediatric population, in addition to the real need for two tests on the same day, regarding their usual indication for evaluation and clinical monitoring of children with chronic diseases. ${ }^{7,14}$

The objective of the present study was to verify the reproducibility of performance and physiological variables (cardiovascular, ventilatory and metabolic) of the 6MWT performed by healthy students.

\section{METHOD}

A prospective cross-sectional study was carried out for three months, which included healthy children, between 6 and 12 years old, from schools of the region of Florianópolis City, Santa Catarina State, Brazil, after approval by the Research Ethics Committee from Universidade do Estado de Santa Catarina, under Opinion No. 708.446 (Certificate of Presentation for Ethical Appreciation 22676113.6.0000.0118). Data collection took place by signing the informed consent form by parents and/or guardians and the child's agreement to the consent form for minors. The participants' healthiness was controlled with the application and analysis of:

- Health record, formulated by the researchers and considering the history and state of the individual with no illness.

- The International Study of Asthma and Allergies in Childhood (ISAAC) questionnaire - module I for asthma control - requiring a score less than 5 for children aged 6 to 9 and less than 6 points for adolescents aged 10 to 14 .

- Spirometry exam, performed using the Easy One Frontline portable equipment (Medical Technologies ${ }^{\circledR}$, Inc., United States), respecting the ATS recommendations. ${ }^{18}$ Those students who presented forced expiratory volume in the first second (FEV1) and forced vital capacity (FVC) with values above $80 \%$ of what was predicted were eligible. ${ }^{19,20}$

Based on data on healthiness control, students with percentiles $\geq 3$ and $<97$, classified as eutrophic and overweight, non-asthmatic and non-performing athletes (enrolled in sports federations) were included from the study. Children and adolescents with disabilities to perform any of the evaluation procedures would be excluded from the sample, which did not happen.

The participants' anthropometric data, body mass and height were evaluated, followed by the calculation of the body mass index (BMI), with the Ministry of Health's Telehealth program (http://www.telessaudebrasil.org.br/apps/calculadoras/). After that, two 6MWTs (6MWT1 and 6MWT2) were conducted, with an interval of 30 minutes between them, in the morning, according to the ATS recommendations. To perform the test, the student was instructed to go as far as possible during the six-minute period and encouraged to do so with standardized phrases said at every minute. ${ }^{10}$ All tests were conducted by the same previously trained evaluators, who measured the blood pressure (BP) and the sensation of dyspnea with the RPE (Rated Perceived Exertion) scale and the modified Borg scale - the first is scored from 0 to 5 , and the second, from 0 to 10 , with 10 representing the maximum symptom..$^{21,22}$ The longest distance covered (DC) between the two tests was considered for analysis, which was recorded in meters. 
For the analysis of physiological responses during the 6MWT, individuals used a K4b2 portable telemetric gas analyzer $\left(\right.$ Cosmed $^{\circledR}$, Italy). The variables respiratory rate (RR), heart rate $(\mathrm{HR})$, minute volume $(\mathrm{MV})$, oxygen consumption $\left(\mathrm{VO}_{2}\right)$, $\mathrm{VO}_{2}$ in relation to body mass $\left(\mathrm{VO}_{2} / \mathrm{kg}\right)$, carbon dioxide production $\left(\mathrm{VCO}_{2}\right)$, gas exchange rate $(\mathrm{R})$, inspiratory time (iT), expiratory time $(\mathrm{e} T)$, total respiratory cycle time (tot $\mathrm{T})$, inspiratory time/total cycle time (iTi/tot $\mathrm{T}$ ) ratio, oxygen saturation (SpO2) and the metabolic equivalent (MET) were collected. For data analysis, variables were measured using the breath-tobreath technique, before and during the two 6MWTs, taking into account the average of the final 15 seconds of the initial rest and the average of the final 15 seconds of each minute of the 6MWT, collected using the gas analyzer. ${ }^{23}$

The sample calculation was based on an expected intraclass correlation coefficient (ICC) of 0.70 for DC in the 6MWT and for physiological variables, considering $\alpha=0.05$ and $\beta=0.10$, totaling a sample of 17 students as sufficient for research. ${ }^{24}$

Statistical analysis was conducted using the IBM Statistical Package for the Social Sciences software (SPSS ${ }^{\circledR}$, Chicago, IL, United States), version 20.0. Initially, data distribution was verified by the Shapiro-Wilk test, and, to compare the physiological variables between the beginning and the end of each of the two 6MWTs, the paired Student's t test, or the Wilcoxon's. The reproducibility of the 6MWT was analyzed with the ICC and the graphic layout of Bland-Altman. The ICC values obtained were interpreted according to the classification by Munro et al., ${ }^{25}$ with little correlation $=\leq 0.25$, low $=0.26-0.49$, moderate $=0.50-0.69$, high $=0.7-0.89$ and very high $=0.9-1.0$. The level of significance adopted was $5 \%$.

\section{RESULTS}

A total of 22 healthy students with a mean age of $10.1 \pm 1.4$ years participated in this study. The average BMI of the students was $17.6 \mathrm{~kg} / \mathrm{m}^{2}( \pm 2.20)$, with most participants classified as eutrophic
(73.9\%), and $26 \%$ of them, as overweight. The characteristics of the sample in relation to age, anthropometric variables and spirometric parameters are described in Table 1.

\section{Reproducibility assessment between the 6MWT1 and the 6MWT2}

By analyzing the reproducibility of DC and the variation of $\mathrm{VO}_{2}$ between the first and the second tests, a high reliability was identified between them, with ICC $=0.76$ (95\% confidence interval $-95 \% \mathrm{CI}, 0.41-0.90 \mathrm{~m}$ ) and $\mathrm{ICC}=0.87$ (95\%CI, 0.68-0.94), respectively. The representation of $\mathrm{VO}_{2}$ behavior is shown in Figure 1, and its reproducibility and that of DC are displayed in Figure 2 by means of Bland-Altman graphs. Moderate to high reliability was also observed between the two 6MWTs, in most physiological parameters, as shown in Table 2, according to the ICC and the limits of agreement.

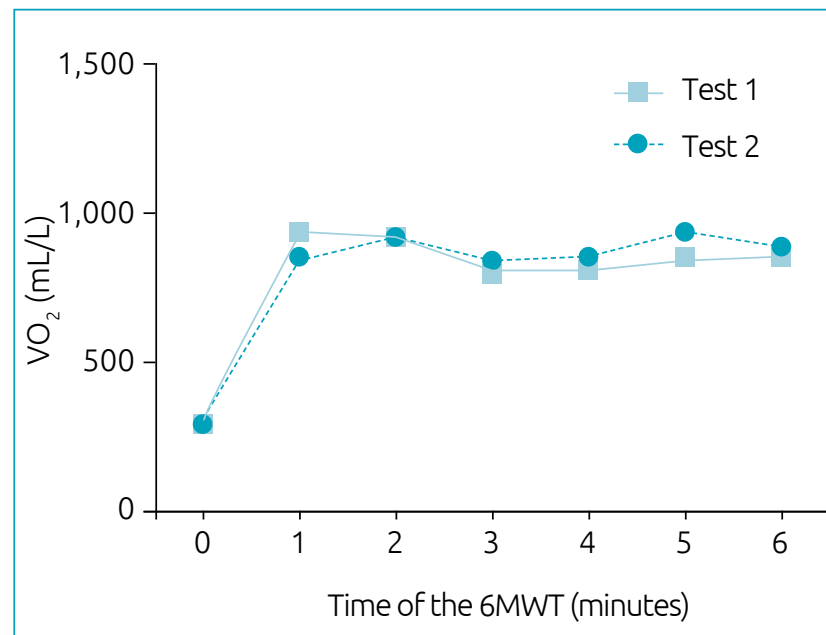

$\mathrm{VO}_{2}$ : oxygen consumption; $\mathrm{mL}$ : mililiter; L: liter; 6MWT: six-minute walk test; Test 1: measurement of the first six-minute walk test; Test 2: measurement of the second six-minute walk test.

Figure 1 Representation of the behavior of the oxygen consumption variable between the two 6MWT.

Table 1 Distribution of age data, anthropometric variables and spirometric parameters of the studied sample.

\begin{tabular}{l|c|c|c}
\hline Parameters & Mean \pm SD & Median & (Minimum-Maximum) \\
\hline Age (years old) & $10.1 \pm 1.4$ & 9.9 & $(7.5-12.9)$ \\
\hline Body mass $(\mathrm{kg})$ & $35.2 \pm 9.0$ & 32.7 & $(24.5-59.6)$ \\
\hline Height $(\mathrm{cm})$ & $1.4 \pm 0.1$ & 1.3 & $(1.2-1.6)$ \\
\hline BMl $\left(\mathrm{kg} / \mathrm{cm}^{2}\right)$ & $17.6 \pm 2.2$ & 17.3 & $(14.1-22.3)$ \\
\hline FEV 1 (\%pred) & $96.3 \pm 9.2$ & 98.0 & $(81-115)$ \\
\hline FVC $(\%$ pred) & $100.6 \pm 10.0$ & 103.4 & $(83-118)$ \\
\hline
\end{tabular}

SD: standard deviation; kg: kilogram; cm: centimeters; BMI: body mass index; FEV; forced expiratory volume in 1 second; FVC: forced vital capacity; \%pred: percentage of what was predicted. ${ }^{20,21}$ 


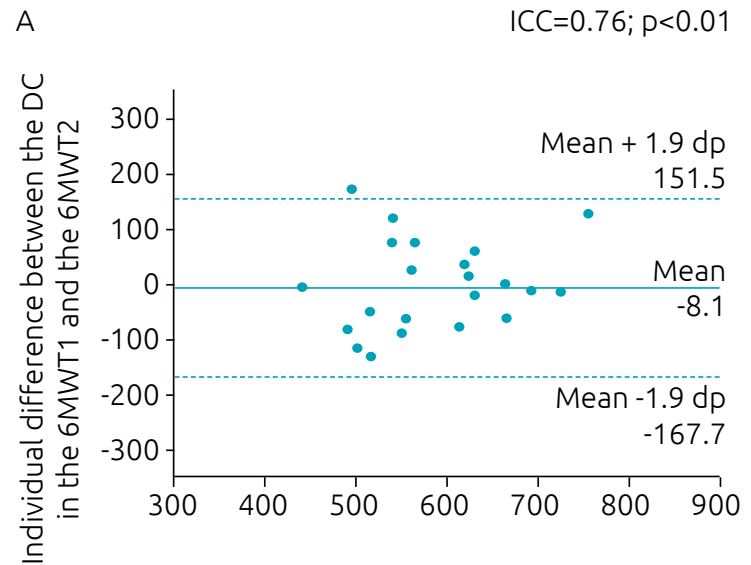

Final mean of DC in the 6MWT (m)
ICC $=0.87 ; p<0.01$

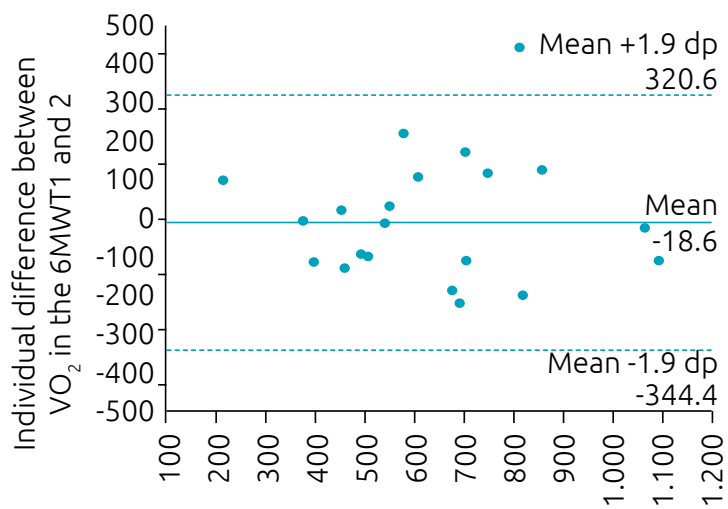

Final mean of $\mathrm{VO}_{2}$ in the $6 \mathrm{MWT}(\mathrm{mL} / \mathrm{min})$

$Y$ axis: distribution of individual differences in distance covered and the $\mathrm{VO}_{2}$ between the two $6 \mathrm{MWTs}$; $\mathrm{X}$ axis: individual means of distances covered and the $\mathrm{VO}_{2}$ during the two 6MWTs; ICC: intraclass correlation coefficient; $\mathrm{VO}_{2}$ : oxygen consumption; DC: distance covered; 6MWT: six-minute walk test; 6MWT1: first six-minute walk test; 6MWT2: second six-minute walk test; m: meter; mL: mililiter; non-continuous line: upper and lower limit of agreement; continuous line: mean between the two tests.

Figure 2 Bland-Altman (A) of the distance covered, and (B) of the behavior of the VO2 physiological parameter between the 6MWT1 and the 6MWT2.

Table 2 Reproducibility of the performance and variation of physiological parameters between the 6MWT1 and the $6 \mathrm{MWT} 2$.

\begin{tabular}{|c|c|c|c|}
\hline & \multicolumn{3}{|c|}{ 6MWT1-6MWT2 } \\
\hline & ICC & $95 \% \mathrm{Cl}$ & p-value \\
\hline Performance (m) & 0.76 & $0.41-0.90$ & 0.001 \\
\hline$\Delta \mathrm{BORG}$ & 0.79 & $0.52-0.91$ & $<0.001$ \\
\hline$\triangle$ RPE scale & 0.63 & $0.09-0.85$ & 0.015 \\
\hline$\Delta \mathrm{RR}(\mathrm{bpm})$ & 0.62 & $0.12-0.84$ & 0.012 \\
\hline$\Delta \mathrm{HR}(\mathrm{bpm})$ & 0.71 & $0.29-0.88$ & 0.004 \\
\hline$\Delta \mathrm{MV}(\mathrm{L} / \mathrm{min})$ & 0.83 & $0.61-0.93$ & $<0.001$ \\
\hline$\Delta \mathrm{VO}_{2}(\mathrm{~mL} / \mathrm{min})$ & 0.87 & $0.68-0.94$ & $<0.001$ \\
\hline$\Delta \mathrm{VO}_{2} / \mathrm{kg}(\mathrm{mL} / \mathrm{min} / \mathrm{kg})$ & 0.77 & $0.45-0.90$ & 0.001 \\
\hline$\Delta \mathrm{VCO}_{2}(\mathrm{~mL} / \mathrm{min})$ & 0.84 & $0.62-0.93$ & $<0.001$ \\
\hline$\Delta \mathrm{R}$ & 0.72 & $0.34-0.88$ & 0.003 \\
\hline$\Delta \mathrm{iT}(\mathrm{s})$ & 0.74 & $0.38-0.89$ & 0.002 \\
\hline$\Delta \mathrm{eT}(\mathrm{s})$ & 0.47 & $-0.26-0.78$ & 0.076 \\
\hline$\Delta \operatorname{totT}(\mathrm{s})$ & 0.56 & $-0.05-0.81$ & 0.034 \\
\hline$\Delta \mathrm{iT} / \operatorname{totT}(\mathrm{s})$ & 0.66 & $0.21-0.86$ & 0.007 \\
\hline$\Delta \mathrm{SpO}_{2}(\%)$ & 0.23 & $-0.50-0.65$ & 0.229 \\
\hline$\triangle \mathrm{METS}$ & 0.77 & $0.45-0.90$ & 0.001 \\
\hline
\end{tabular}

6MWT1: first six-minute walk test; 6MWT2: second six-minute walk test; ICC: intraclass correlation coefficient; $95 \% \mathrm{Cl}$ : $95 \%$ confidence interval; p-value: reliability test value; $\Delta$ : variation ( $\Delta=$ final-initial); BORG: dyspnea scale (points); RPE scale: rated perceived exertion scale (points); RR: respiratory rate; $\mathrm{HR}$ : heart rate; $\mathrm{MV}$ : minute volume; $\mathrm{VO}_{2}$ : oxygen consumption; $\mathrm{VO}_{2} / \mathrm{kg}: \mathrm{VO}_{2}$ in relation to body mass; $\mathrm{VCO}_{2}$ : carbon dioxide production; $\mathrm{R}$ : gas exchange rate; iT: inspiratory time; $\mathrm{eT}$ : expiratory time; totT: total time of respiratory cicle; iT/totT: inspiratory time/total cycle time ratio; $\mathrm{SpO}_{2}$ : oxygen saturation; METS: metabolic equivalent for oxygen; $m$ : meters; bpm: breaths per minute; bpm: beats per minute; L: liters; min: minute; mL: mililiter; kg: kilogram; s: seconds.
There was no difference in performance between the two 6MWTs. The distances covered in the first $(584.8 \pm 85.1)$ and in the second test $(584.9 \pm 97.5)$ were similar. The analysis of the variation in cardiovascular, ventilatory and metabolic parameters between the 6MWT1 and the 6MWT2 did not identify any difference in any of the studied variables either. Table 3 contains the result of the comparison of the performance measures and the variation of the physiological parameters between the 6MWT1 and the 6MWT2, as well as the average data and the standard deviation.

\section{DISCUSSION}

The present study analyzed the reproducibility of DC and the physiological responses triggered by two 6MWTs performed by healthy children and adolescents. Based on the identification of low magnitude correlations in the $\mathrm{e} \mathrm{T}$ and $\mathrm{SpO} 2$ variables, moderate in the RPE scale, RR, tot $\mathrm{T}$ and $\mathrm{iT} /$ tot $\mathrm{T}$ variables, as well as the high reliability in DC, Borg, $\mathrm{HR}, \mathrm{MV}, \mathrm{VO}_{2}, \mathrm{VO}_{2} / \mathrm{Kg}, \mathrm{VCO}_{2}$, $\mathrm{R}$, iT and metabolic equivalent for oxygen (METS), between the two tests performed by the same population of students, it can be said that the 6MWT is reproducible in this group. In the same vein, some studies had already found the reproducibility of this test in the healthy pediatric population, ${ }^{15,16}$ as well as in the behavior of cardiorespiratory parameters, assessed in a standard way. A study that included the presence of a gas analyzer to assess the behavior of the physiological parameters of healthy students during the 6MWT had not yet been conducted, which justifies this investigation and attributes it to being a pioneer. 
Table 3 Result of the comparison of the performance measures and the variation of physiological parameters, between the 6MWT1 and the 6MWT2, as well as the data of mean and standard deviation.

\begin{tabular}{|c|c|c|c|c|c|}
\hline & & & & & م \\
\hline & Mean \pm SD & Min-Max & Mean $\pm S D$ & Min-Max & p-value \\
\hline Performance & $584.8 \pm 85.1$ & $408.0-730.6$ & $584 \pm 97.5$ & $437-818$ & 0.96 \\
\hline$\triangle \mathrm{BORG}^{\star}$ & $0.4 \pm 1.0$ & $0.0-4.0$ & $0.1 \pm 0.6$ & $0.0-3.0$ & 0.12 \\
\hline$\triangle$ RPE scale* & $0.8 \pm 1.0$ & $0.0-4.0$ & $0.8 \pm 1.1$ & $0.0-4.0$ & 1.00 \\
\hline$\Delta \mathrm{RR}$ & $18.6 \pm 8.4$ & $6.0-37.5$ & $21.4 \pm 7.7$ & $5.4-38.0$ & 0.12 \\
\hline$\Delta \mathrm{HR}$ & $42.8 \pm 19.8$ & $0.7-77.1$ & $43.2 \pm 17.3$ & $17.3-80.5$ & 0.91 \\
\hline$\Delta \mathrm{MV}$ & $16.0 \pm 5.0$ & $4.6-24.3$ & $16.6 \pm 6.8$ & $6.0-30.6$ & 0.56 \\
\hline$\Delta \mathrm{VO}_{2}$ & $643.3 \pm 232.5$ & $163.3-1.138 .9$ & $656.0 \pm 260.9$ & $261.4-1219.5$ & 0.72 \\
\hline$\Delta \mathrm{VO}_{2} / \mathrm{kg}$ & $18.2 \pm 5.0$ & $6.0-27.7$ & $18.5 \pm 5.9$ & $9.6-31.3$ & 0.76 \\
\hline$\Delta \mathrm{VCO}_{2}$ & $600.5 \pm 203.7$ & $154.6-999.4$ & $610.6 \pm 251.6$ & $194.3-1.181 .7$ & 0.78 \\
\hline$\Delta \mathrm{R}$ & $-0.0 \pm 0.1$ & $-0.3-0.1$ & $-0.0 \pm 0.1$ & $-0.2-0.1$ & 0.71 \\
\hline$\Delta \mathrm{i} T^{*}$ & $-0.4 \pm 0.3$ & $-1.4-0.0$ & $-0.4 \pm 0.3$ & $-1.4-(-0.0)$ & 0.68 \\
\hline$\Delta \mathrm{eT}^{*}$ & $-0.9 \pm 0.5$ & $-2.1-(-0.1)$ & $-1.1 \pm 0.8$ & $-4.2-(-0.3)$ & 0.42 \\
\hline$\Delta \operatorname{tot} T^{*}$ & $-1.4 \pm 0.8$ & $-3.5-(-0.1)$ & $-1.6 \pm 0.9$ & $-5.0-(-0.3)$ & 0.57 \\
\hline$\Delta \mathrm{iT} /$ totT* & $0.0 \pm 0.0$ & $-0.0-0.1$ & $0.0 \pm 0.0$ & $0.0-0.2$ & 0.45 \\
\hline$\Delta \mathrm{SpO}_{2}{ }^{*}$ & $-0.5 \pm 1.1$ & $-3.0-1.5$ & $-1.6 \pm 1.8$ & $-7.0-0.8$ & 0.03 \\
\hline$\Delta$ METS & $5.2 \pm 1.4$ & $1.7-7.9$ & $5.3 \pm 1.6$ & $2.7-8.9$ & 0.76 \\
\hline
\end{tabular}

6MWT1: first six-minute walk test; 6MWT2: second six-minute walk test; SD: standard deviation; Min: minimum; Max: maximum; p-value: statistical test value; * variables with non-parametric distribution analyzed with the Wilcoxon test; $\Delta$ : variation ( $\Delta=$ final-initial); BORG: dyspnea scale (points); RPE scale: rated perceived exertion scale (points); RR: respiratory rate; HR: heart rate; $M V$ : minute volume; $\mathrm{VO}_{2}$ : oxygen consumption; $\mathrm{VO}_{2} / \mathrm{kg}$ : VO2 in relation to body mass; $\mathrm{VCO}_{2}$ : carbon dioxide production; R: gas exchange rate; iT: inspiratory time; eT: expiratory time; totT: total time of respiratory cicle; iT/totT: inspiratory time/total cycle time ratio; SpO2: oxygen saturation; METS: metabolic equivalent for oxygen.

Leunkeu et al., ${ }^{11}$ among their analyzes, demonstrated the reproducibility of the DC variables and the physiological responses collected in the 6MWT, using a portable gas analyzer, in a sample of children and adolescents $(14.2 \pm 1.8$ years ) with cerebral palsy, classified in levels I and II of the Gross Motor Function Classification System (GMFCS). The values obtained in the two 6MWT were reproducible, with high reliability for DC (ICC $=0.80$ and $\mathrm{DC}=395 \pm 95$ vs. $421 \pm 100 \mathrm{~m}, \mathrm{p}=0.53$ ), and also for the physiological response variables $\left(\mathrm{VO}_{2}\right.$ peak: $\mathrm{ICC}=0.85$; $\mathrm{MV}$ peak: $\mathrm{ICC}=0.83$; maximum HR: ICC $=0.82$ ). These results were like those obtained in the present study.

Among the physiological variables, oxygen consumption is interpreted in the literature as the main index of aerobic fitness during exercise. ${ }^{26}$ In view of this, in Pediatrics, the study by Bos et al. ${ }^{27}$ used $\mathrm{VO}_{2}$ peak to determine the level of physical activity and the aerobic fitness of children aged 6 to 12 undergoing liver transplantation. The assessment consisted of the gas analysis measured using the cardiopulmonary exercise test (CPET), considered the gold standard for this assessment. Among the variables, $\mathrm{VO}_{2}, \mathrm{VO}_{2}$ peak, $\mathrm{MV}$ and $\mathrm{VCO}_{2}$ were calculated, which defined that children have normal levels of aerobic conditioning.

The study of the measures obtained by gas analysis during tests to evaluate functional capacity and exercise in children enables the knowledge of the changes that these tests trigger in the arterial and venous partial pressures of gases, as well as possible ventilatory limitations during exertion (cardiovascular, respiratory and muscular or metabolic), in addition to assessing the behavior of stroke volume, obtained by analyzing the curves and the maximum values of the oxygen pulse $\left(\mathrm{VO}_{2} /\right.$ $\mathrm{HR})$ and ventilatory equivalents $\left(\mathrm{MV} / \mathrm{VO}_{2}\right.$ and $\left.\mathrm{MV} / \mathrm{VCO}_{2}\right)$, when an incremental protocol was performed. ${ }^{28}$ Therefore, the absence of CPET can be considered a limitation of the present study, considering that the data used as parameters for comparison with the responses obtained in the 6MWT were with prediction equations.

On the other hand, Pereira et al..$^{14}$ assessed functional performance on the 6MWT in two different populations: students with cystic fibrosis $(\mathrm{n}=55)$ and healthy students $(\mathrm{n}=185)$, whose mean ages were $12.2 \pm 4.3$ and $11.3 \pm 4.3$ years, respectively. The results showed that the DC achieved between the first and the second 
tests were similar in both groups. These findings confirmed the reproducibility of the 6MWT, with high correlations, both for the group with cystic fibrosis (ICC $=0.81$ ) and the healthy one (ICC=0.77), and the ICC result for the healthy population was similar to that observed in the current investigation.

Along the same line, Cunha et al. ${ }^{29}$ evaluated the performance related to the clinical variables of children with cystic fibrosis (11.0 \pm 1.9 years), with a mean $\% \mathrm{FEV}_{1}$ of $63.1( \pm 21.1)$, and did not identified a significant difference between the means of DC $(582.3 \pm 60$ and $598.2 \pm 56.8 \mathrm{~m}$ ), of cardiorespiratory responses and the sensation of dyspnea between the two 6MWTs. In obese students, the same pattern was verified by Morinder et al..$^{30}$ in a study whose sample included ages between 8 and 16 , and the test-retest was reproducible with high reliability $(\mathrm{ICC}=0.84)$ in this group. As to obesity, it is worth mentioning that almost $30 \%$ of the current research sample was characterized by being overweight, which can be considered a limitation, because it is known that this profile of individuals can present impairment in the performance of physical exercise.

The behavior of adult individuals during the 6MWT is well established, with a consensus on the presence of the learning effect in the performance of the test, ${ }^{13}$ which reinforces the guidelines regarding the need to perform two tests. ${ }^{10}$ In children with chronic kidney disease, this pattern was verified by Watanabe et al., ${ }^{8}$ in a study that evaluated the reproducibility of the 6MWT in 38 children and adolescents (6 and 16 years old), who were on dialysis or had undergone kidney transplantation. The authors found that this population had a greater distance covered in the second test $(519 \mathrm{~m}(362-$ 674) vs. $538.5 \mathrm{~m}(405-685) ; \mathrm{p}<0.001)$, with low reliability between them (ICC>0.4). According to the authors, in this specific condition, there is a need for test-retest, as described by the ATS. ${ }^{10}$

In Pediatrics, the need for two tests is still discussed. In this sense, two studies evaluated healthy children and noted high reproducibility of DC in the $6 \mathrm{MWT}^{15,16}$ (ICC $=0.82$ and $\mathrm{ICC}=0.84$, respectively), but did not show a learning effect in the referred investigations, with similar DC between the test-retest. Martins et al. ${ }^{15}$ attributed this behavior to the fact that healthy children are motivated by the novelty in view of the first test and do not commit themselves so much to the repetition of a second 6MWT, because the test is now known.

The results of the present study reflect the characteristics of a sample of healthy children, which can be considered a limitation of this investigation. Therefore, it is recommended to carry out further research in this line, including populations of chronic pulmonary patients and other specific situations, given the importance of monitoring the functional capacity in these individuals and identifying results similar to those presented here. This is because the application of a single test can be discussed for these individuals, which simplifies its application and performance, since the repetition of the 6MWT requires greater energy expenditure, which may not be indicated in critically ill patients. In addition, saving time spent for two 6MWTs increases its feasibility and applicability both in outpatient settings and in epidemiological studies conducted externally and, therefore, justifies further investigations.

The results shown here, which verified similarity in performance and in the response of physiological variables in the execution of two 6MWTs, suggest the possibility of conducting a single test in populations of healthy children.

\section{Funding}

We thank the support for infrastructure for research groups FAPESC 522/2017, grant term No. 2017TR645.

\section{Conflict of interests}

The authors declare there is no conflict of interests.

\section{REFERENCES}

1. Leidy NK. Functional status and the forward progress of merry-go-rounds: toward a coherent analytical framework. Nurs Res. 1994;43:196-202.

2. Kocks JW, Asijee GM, Tsiligianni IG, Kerstjens HA, Molen T. Functional status measurement in COPD: a review of available methods and their feasibility in primary care. Prim Care Respirat J. 2011;20:269-75. https://doi.org/10.4104/pcrj.2011.00031

3. Bohannon RW, Bubela DJ, Wang YC, Magasi SS, Gershon RC. Six-minute walk test versus three-minute step test for measuring functional endurance (alternative measures of functional endurance). J Strength Cond Res. 2015;29:3240-4. https://doi.org/10.1519/JSC.0000000000000253
4. Vaidya T, Chambellan A, Bisschop C. Sit-to-stand tests for COPD: a literature review. Respir Med. 2017;128:70-7. https://doi.org/10.1016/j.rmed.2017.05.003

5. Maggio $A B$, Vuistiner $P$, Crettenand $A$, Tabin $R$, Martin XE, Beghetti $M$, et al. Adapting the "Chester step test" to predict peak oxygen uptake in children. Swiss Med Wkly. 2017;147:w14435. https://doi.org/10.4414/ smw.2017.14435

6. Martins R, Assumpção MS, Bobbio TG, Mayer AF, Schivinski C. The validity and reliability of the ADL-Glittre test for children. Physiother Theory Pract. 2019;35:773-780. https:// doi.org/10.1080/09593985.2018.1457747 
7. Lima CA, Andrade AD, Campos SL, Brandão DC, Mourato IP, Britto MC. Six-minute walk test as a determinant of the functional capacity of children and adolescents with cystic fibrosis: a systematic review. Respir Med. 2018;137:83-8. https://doi.org/10.1016/j.rmed.2018.02.016

8. Watanabe FT, Koch VH, Juliani RC, Cunha MT. Six-minute walk test in children and adolescents with renal diseases: tolerance, reproducibility and comparison with healthy subjects. Clinics (São Paulo). 2016;71:22-7. https://doi. org/10.6061/clinics/2016(01)05

9. Cacau LA, Santana-Filho VJ, Maynard LG, Gomes Neto M, Fernandes M, Carvalho VO. Reference values for the six-minute walk test in healthy children and adolescents: a systematic review. Braz J Cardiovasc Surg. 2016;31:381-8. https://doi.org/10.5935/1678-9741.20160081

10. Holland AE, Spruit MA, Troosters T, Puhan MA, Pepin V, Saey $D$, et al. An official European Respiratory Society/American Thoracic Society technical standard: field walking tests in chronic respiratory disease. Eur Respir J. 2014;44:1428-46. https://doi.org/10.1183/09031936.00150314

11. Nsenga Leunkeu A, Shephard RJ, Ahmaidi S. Six-minute walk Test in children with cerebral palsy gross motor function classification system levels i and ii: reproducibility, validity, and training effects. Arch Phys Med Rehabil. 2012;93:2333-9. https://doi.org/10.1016/j.apmr.2012.06.005

12. Donadio MV, Heinzmann-Filho JP, Vendrusculo FM, Frasson PX, Marostica PJ. Six-minute walk test results predict risk of hospitalization for youths with cystic fibrosis: a 5-year follow-up study. J Pediatr. 2017;182:204-9.e1. https://doi. org/10.1016/j.jpeds.2016.11.071

13. Hernandes NA, Wouters EF, Meijer K, Annegarn J, Pitta F, Spruit MA. Reproducibility of 6-minute walking test in patients with COPD. Eur Respir J. 2011;38:261-7. https:// doi.org/10.1183/09031936.00142010

14. Регеiгa FM, Ribeiro MÂ, Ribeiro AF, Toro AA, Hessel G, Ribeiro JD. Functional performance on the six-minute walk test in patients with cystic fibrosis. J Bras Pneumol. 2011;37:735-44. https://doi.org/10.1590/S180637132011000600006

15. Martins R, Gonçalves RM, Mayer AF, Schivinski Cl. Reliability and reproducibility of six-minute walk test in healthy children. Fisioter Pesqui. 2014;21:279-84. https://doi.org/10.590/18092950/92221032014

16. Morales Mestre N, Audag N, Caty G, Reychler G. Learning and encouragement effects on six-minute walking test in children. J Pediatr. 2018;198:98-103. https://doi.org/10.1016/j. jpeds.2018.02.073

17. Okuro RT, Schivinski Cl. Teste de caminhada de seis minutos em pediatria: relação entre desempenho e parâmetros antropométricos. Fisioter Mov. 2013;26:219-28. https:// doi.org/10.1590/S0103-51502013000100024
18. Miller MR, Hankinson J, Brusasco V, Burgos F, Casaburi R, Coates A, etal. Standardisation of spirometry. Eur Respir J. 2005;26:31938. https://doi.org/10.1183/09031936.05.00034805

19. Knudson RJ, Slatin RC, Lebowitz MD, Burrows B. The maximal expiratory flow-volume curve. Normal standards, variability, and effects of age. Am Ver Respir Dis. 1976;113:587-600. https://doi.org/10.1164/arrd.1976.113.5.587

20. Polgar C, Weng TR. The functional development of the respiratory system from the period of gestation to adulthood. Am Rev Respir Dis. 1979;120:625-95. https://doi.org/10.1164/ arrd.1979.120.3.625

21. Cavalcante TD, Diccini S, Barbosa DA, Bittencourt AR. The use of Borgís modified scale in asthma crises. Acta Paul Enferm. 2008;21:466-73. https://doi.org/10.1590/S010321002008000300014

22. Scalco JC, Martins R, Keil PMR, Mayer AF, Schivinski CIS. Psychometric properties of functional capacity tests in children and adolescents: systematic review. Rev Paul Pediatr. 2018;36:500-10. doi:10.1590/19840462/;2018;36;4;00002

23. Scalco JC. Respostas ventilatórias, cardiovasculares e metabólicas induzidas por testes de exercício em escolares saudáveis [master's thesis]. Florianópolis: UDESC; 2015.

24. Hulley SB, Cummings SR, Browner WS, Grady D, Hearst N, Newman TB. Designing Clinical Research. $4^{\text {th }}$ ed. Philadelphia: Lippincott Williams and Wilkins; 2013.

25. Munro BH. Munro's statistical methods for health care research. $3^{\text {rd }}$ ed. New York: Lippincott Williams \& Wilkins; 1997.

26. Sanabria D, Luque-Casado A, Perales JC, Ballester R, Ciria LF, Huertas $F$, et al. The relationship between vigilance capacity and physical exercise: a mixed-effects multistudy analysis. PeerJ. 2019;7:e7118. https://doi.org/10.7717/peerj.7118

27. Bos GJ, Lelieveld OT, Scheenstra R, Sauer PJ, Geertzen $\mathrm{JH}$, Dijkstra PU. Physical activity and aerobic fitness in children after liver transplantation. Pediatr Transplant. 2019;23:e13465. https://doi.org/10.1111/petr.13465

28. Ghorayeb N, Stein R, Daher DJ, Silveira AD, Ritt LE, Santos DF, et al. Atualização da Diretriz em Cardiologia do Esporte e do Exercício da Sociedade Brasileira de Cardiologia e da Sociedade Brasileira de Medicina do Esporte - 2019. Arq Bras Cardiol. 2019;112:326-68. https://doi.org/10.5935/abc.20190048

29. Cunha MT, Rozov T, de Oliveira RC, Jardim JR. Six-minute walk test in children and adolescents with cystic fibrosis. Pediatr Pulmonol. 2006;41:618-22. https://doi.org/10.1002/ppul.20308

30. Morinder G, Mattsson E, Sollander C, Marcus C, Larsson UE. Six-minute walk test in obese children and adolescents: reproducibility and validity. Physiother Res Int. 2009;14:91104. https://doi.org/10.1002/pri.428 